\title{
THE INFLUENCE OF CLIMATE ELEMENTS ON THE YIELD OF AGRICULTURAL CROPS IN THE AREA OF SUMADIJA IN SERBIA
}

\author{
Gordana Petrović, Bojan Labović2, Boban Dašić ${ }^{3}$ \\ *Corresponding author E-mail: milicakg98@yahoo.com
}

\begin{abstract}
A R T I C LE IN F O
A B S T R A C T

Review Article

Received: 27 September 2018

Accepted: 11 March 2019

doi:10.5937/ekoPolj1901173P

UDC 551.5:631.559(497.11)

Keywords:

Climate elements, agricultural

The goal of this paper is to examine the existence of correlation between temperature and precipitation as independent variables and crop yield (wheat, corn) as dependent variable by applying Spearman's rank correlation coefficient. As the research field, region of Gruža is taken, more precisely county of Knić. Climate features of previously mentioned territory are obtained by monitoring the climate elements condition (temperature and precipitation) for the time period from 1991 to 2011 in crops, Spearmans rank correlation coefficient, Gruža, climate changes. weather stations Kragujevac, Kraljevo and Rudnik. Shifts in climate elements values are usually consequences of climate changes, which manifest in our country and shave significant impact to crop yield.
\end{abstract}

JEL: Q10, Q54

(C) 2019 EA. All rights reserved.

\section{Introduction}

Both, World Meteorological Organization (WMO) and The United Nations Environment Programme (UNEP) founded Intergovernmental Panel on Climate Change (IPCC) in 1988, based in Geneva (Switzerland), whose work is done in accordance with principles of previously mentioned organizations. The first report about climate change is published in 1990 and it initiated the founding of UN Framework Convention on climate change. Then, in 1995, the international community was alarmed due to the possible impact of human activity on climate, which hastened the adoption of Kyoto Protocol. The third report from 2001 reaffirmed human impact on climate change, and in the fourth report, in 2007, the urge to prevent releasing of gases which provoked greenhouse effects was emphasized. The fifth report from 2013 showed that human impact on climate change increased, as well as its consequences which could be detected on Planet.

1 Gordana Petrović Ph.D., Geography teacher, independent researcher, Phone: +381 64 1892281, E-mail: milicakg98@yahoo.com, ORCID iD 0000-0001-5104-2348 (https:// orcid.org/0000-0001-5104-2348)

2 Bojan Labović, Master economist, High Economic School of Vocational Studies PecLeposavic, Phone number: +381 641905599, E-mail: labovic.bojan@gmail.com, ORCID iD 0000-0003-2168-3296 (https://orcid.org/0000-0003-2168-3296)

3 Boban Dašić, Ph.D., Assistant Professor, Alfa University, Faculty of Finance, Banking and Auditing, Belgrade, Phone: +381 646265211, E-mail: bobandasickg@gmail.com, ORCID iD 0000-0003-1980-8707 (https://orcid.org/0000-0003-1980-8707) 
Climate is the primary determinant of agricultural productivity, especially in the cases of developing countries, in which agriculture basically depends on natural circumstances. Possible scenarios of climate change namely temperature increase, precipitation change, extreme climate change such as drought, floods and landslides, and higher $\mathrm{CO}_{2}$ concentration would directly impact the yield. Generally, temperature increase would lower the yield and also the quality of food crops thus jeopardizing food supplies. Similarly, changes in precipitation pattern, such as intensive rain concentrated in a particular month, has a devastating effect on crop production (Prakash et.al. 2011).

Estimates show that if measures to abate global warming are not carried out, global agricultural productivity will be reduced for 15,9 percent by the $2080 \mathrm{~s}$, and when it comes to the developing countries, a disproportionately large decline of 19,7 percent would be experienced (Kelbore, 2012).

Reports of Intergovernmental Panel unambiguously state that climate change exists. The cause for global warming on the Earth is increased concentration of gasses GHG (Greenhouse Gases-GHGs) in the atmosphere. In 2015, the Republic of Serbia presented national goals for reduction of $\mathrm{CO}_{2}$ emission until 2030 for 9,8 percent, in comparison to the referent year 1990. Due to the increasing accumulation of $\mathrm{CO}_{2}$, which is treated as significant pollutant and causer of greenhouse effect, in the atmosphere, carbon dioxide emission in the world increased for 51,3 percent for the time period 1971-2012, while in Serbia, it decreased for 28,2 percent for the period 1990-2012. (http://www.euractiv. rs/odrzivi-razvoj/8826-smanjenje-c02-u-srbiji-napredak-ili-varka.html)

The fifth report of Intergovernmental Panel about Climate Change(IPCC) confirms that human is responsible for climate change and global warming. Human neglect call in question the survival on Planet Earth. Climate change, as well as natural disasters, are result of human negative influence on the environment. According to the best case scenario, global surface temperature by the end of $21^{\text {st }}$ century would exceed $1,5^{\circ} \mathrm{C}$, and according to the worst case scenario, global surface temperature would exceed $2{ }^{\circ} \mathrm{C}$ in comparison to the time period from 1850 to 1900 (The Intergovernmental Panel on Climate Change, 2014). The goal of UN Framework Convention on Climate Change „Paris 2015 " is to achieve new international agreement on climate which will apply to all countries and also to keep the global warming below $2^{\circ} \mathrm{C}$ (Jayaraman, 2015).

Climate Change prevention is strategic priority of EU. European commission and EU Member States have developed the strategy which should resist to inevitable influence of climate change. The goal of EU is to, through binding regulations, meet three key moments which are also called energy package, by the year 2020. It is necessary to reduce emission of greenhouse gases by 20 percent, in comparison to the year 1990. The share of energy used in EU from renewable resources should be up to 20\% and energy efficiency improvement should be 20\% (Netherlands Environmental Assessment Agency, 2013).

There are more and more natural disasters in the world as well as in the Republic of Serbia, and they usually occur as consequences of climate change effect. Most often in our country, it is talked about natural disasters in the period of their occurrence 
and it is dealt with the consequences, instead of applying precautionary measures in order to potential disaster effects. It is necessary to put precautionary measure focus on dangers that threatens the Republic of Serbia. These dangers are heat waves, forest fires, droughts, floods, tempests and other disasters. „It is esteemed that the total material damage caused by extreme climate and weather conditions in 2000 exceeds 5 billion of EUR, and more than $70 \%$ of loss was connected to the droughts and high temperatures. Another main cause for significant losses are floods. In 2014, floods caused enormous damage and it was esteemed that it would be necessary 1,35 billion of EUR for the recovery (Jovović, Jovičić, 2017)." Climate change has significant impact on agriculture, especially extreme climate events such as droughts, heat waves and floods. It is expected that, projected increase of extreme climate events would additionally increase crop-yield variability.

\section{Geographical characteristics of the area}

Region of Gruža was selected as the research area. This is a small geographic entity located in Šumadijawhose territory includes valley of the river Gruža, after which it was named. It extends in a northwest-southeast direction and it is opened to valley of West Morava. The largest part of it belongs to the basin with the same name, which lies between Rudnik (1132 m), Kotlenik (749 m) and Gledić Mountains. Gruža covers an area of $622 \mathrm{~km}^{2}$. It includes countryside of boroughs Knić, GornjiMilanovac, Kraljevo and Kragujevac. The largest area in the region of Gruža belongs to the borough Knić. It is the area of $413 \mathrm{~km}^{2}$ with 36 settlements with rural characteristics. The borough borders borough of Kragujevac on the northwest, which is $20 \mathrm{~km}$ distant, then on northwest borough GornjiMilanovac, $40 \mathrm{~km}$ distant, then on the westČačak, $38 \mathrm{~km}$ distant, and on the South Kraljevo, $40 \mathrm{~km}$ distant. It belongs to the group of undeveloped boroughs whose citizenship are predominantly engaged in agriculture. According to the Regional Development Law, it is a local self-government unit which by degree of development, belongs to the IV group (Official Gazette of the Republic of Serbia, 2015). Development degree in this county is $60 \%$ below national average. The most important natural potential of county Knić is available agricultural land that covers about $60 \%$ of total area. Fertile land around river Gruža is suitable for crops cultivation. $80 \%$ of available agricultural land is being used. According to the manner of use, the most important categories of the land structure, are arable land and gardens which cover $63,5 \%$ (12.223 ha). Cereals and vegetables are mostly cultivated.

\section{Data and methodology}

Agriculture is the branch of economy which by its nature is closely dependent to climate conditions. Climate features on the territory of Gruža with certain local deviations are showed by comparative observations of nearby weather stations in Kragujevac (185 $\mathrm{m} ; \varphi=44^{\circ} 02^{\prime}, \lambda=20^{\circ} 56^{\prime}$ ), Kraljevo (215 m; $\varphi=43^{\circ} 43^{\prime}, \lambda=20^{\circ} 42^{\prime}$ ) and on the mountain Rudnik ( $\left.700 \mathrm{~m} ; \varphi^{\prime}=44^{\circ} 08^{\prime}, \lambda=20^{\circ} 31^{\prime}\right)$. Climate element conditions are shown for the period from 1991 to 2011. Two meteorological parameters, air temperature (yearly, 
monthly minimal and maximal) and precipitation quantity (data by month and annual precipitation quantity) were observed. Meteorological data were obtained by using of Meteorological yearbooks of Republic Hydrometeorological Institutefor the specific time period and then they were processed by months and year.

Two agricultural crops were chosen for the research on the area of Gruža, wheat and corn. Data about crop yield (kg/ha) were obtained by using data from Statistical Office of the Republic of Serbia. The same period of observation was selected (1991-2011). All data were processed by applying software package SPSSS Statistics 25.

The goal of the report is to examine existence of the correlation between air temperature (maximal and minimal) and precipitation quantity which were taken as predictor variables and crop yield (wheat, corn) which were taken as criterion variables. In order to confirm or deny the relationship, Spearman's correlation test was applied.

\section{Results and discussion}

In the initial phase of statistical analysis, in order to describe statistical data, the descriptive statistics method was applied. This type of analysis was made for precipitation and temperature for the area of Gruža.

Table 1.Maximal and minimal annual temperature $\left({ }^{\circ} \mathrm{C}\right)$ and annual precipitation quantity (mm) in the area of Gruža for the period 1991-2011.

\begin{tabular}{|c|c|c|c|c|c|c|c|}
\hline & \multicolumn{7}{|c|}{ Maximal temeprature } \\
\hline & $\mathbf{N}$ & Range & Min. & Max. & Mean & Std. Dev. & Variance \\
\hline Kragujevac & 21 & 3,9 & 15,9 & 19,8 & 17,800 & ,9088 & 826 \\
\hline Kraljevo & 21 & 3,6 & 15,7 & 19,3 & 17,367 & ,9313 & 867 \\
\hline \multirow[t]{3}{*}{ Rudnik } & 13 & 2,8 & 12,3 & 15,1 & 13,746 & ,9052 & ,819 \\
\hline & \multicolumn{7}{|c|}{ Minimal temperature } \\
\hline & $\mathbf{N}$ & Range & Min. & Max. & Mean & Std. Dev. & Variance \\
\hline Kragujevac & 21 & 2,1 & 5,5 & 7,6 & 6,719 &, 5750 & ,331 \\
\hline Kraljevo & 21 & 2,1 & 5,2 & 7,3 & 6,495 & ,5723 & ,327 \\
\hline \multirow[t]{3}{*}{ Rudnik } & 20 & 2,2 & 5,8 & 8,0 & 6,810 & 6512 & ,424 \\
\hline & \multicolumn{7}{|c|}{ Precipitation } \\
\hline & $\mathbf{N}$ & Range & Min. & Max. & Mean & Std. Dev. & Variance \\
\hline Kragujevac & 21 & 460,7 & 378,8 & 839,5 & 626,238 & 136,050 & 18509,84 \\
\hline Kraljevo & 21 & 404,3 & 499,8 & 904,1 & 725,319 & 118,763 & 14104,68 \\
\hline Rudnik & 20 & 734,0 & 519,9 & 1253,9 & 933,475 & 198,056 & 39226,24 \\
\hline
\end{tabular}

Author processed the data via program SPSS Statistics 25.

Table 1 displays descriptive statistics of maximal and minimal annual temperatures for weather stations Kragujevac, Kraljevo and Rudnik for the period from 1991 to 2011. Meteorological data for certain years from weather station Rudnik are missing. The 
sample is processed for the period of 21 years $(\mathrm{N}=21)$, while for Rudnik it is taken period of 13 to 15 years for maximal temperatures and 20 years for minimal temperatures. Data shows that in the selected time period, the highest maximal temperature was $19,8^{\circ} \mathrm{C}$ (Kragujevac), $19,3^{\circ} \mathrm{C}$ (Kraljevo) and $15,1^{\circ} \mathrm{C}$ (Rudnik). The lowest maximal temperature was $15,9^{\circ} \mathrm{C}$ (Kragujevac), $15,5^{\circ} \mathrm{C}$ (Kraljevo) and $12,3^{\circ} \mathrm{C}$ (Rudnik).

Data in the second column (Range) display differences between maximal and minimal temperatures. Average temperatures are displayed in the fifth column (Mean).

Standard deviations show how big the deviation on average from mean value is. Variance show which part of mean is standard deviation. Variance and standard deviation are in direct relationship because variance is square of standard deviation, and standard deviation is square root of variance.

When we look at the values of minimal and maximal temperatures, we can notice that there is slightly bigger deviation in weather station Rudnik. Temperature is significant factor which impact seed germination of wheat and corn. Optimal temperatures stimulate good germination ability, while too low or too high temperatures have negative effect, because they lead to prolongation or delay of germination period. Low temperatures during fall or extreme heat waves in spring are the biggest cause for yield loss.

When it comes to the precipitation quantity for the period 1991-2011, it could be noticed that there are significantly higher mean, minimal and maximal values of precipitation quantity in weather station Rudnik. Because of significantly bigger precipitation quantities in the previously mentioned weather station in comparison to other two weather stations, it could be noted also bigger deviation from mean precipitation quantity.

The correlation represents statistical procedure for calculation two variables. The correlation value is expressed numerically via "Spearman's correlation coefficient". Spearman's correlation coefficient (rs) is linear correlation coefficient which values range from -1 to +1 . The closer the absolute value is to number 1 the bigger correlation is between variables. Small $r$ value, however, could be important and it depends from joined $r$ value. If this $r$ value is below the level of significance $(r=0,05)$ then the zero hypothesis will not be rejected, and correlation coefficient would be considered as statistically significant (Zar, 1984)." Correlation coefficient indicates the strength and direction of correlation. Value of correlation coefficient that varies from 0 to 1 shows that the correlation is positive and indicates consistent growth of both variable values. Value of correlation coefficient between 0 and -1 means negative correlation, or to put it differently, increase in value of one variable and decline in value of another one. Complete relationship of correlation coefficient values is \pm 1 . When correlation coefficient has value 0 , it indicates the absence of linear relationship and points to the fact that if we knew the value of one variable we still would not conclude anything about the value of another one.

The most evident weather conditions for yield productivity are precipitation and temperature during vegetation. However, more weather variables, such as solar 
radiation and relative humidity, could also affect the yield, as well as adverse weather periods during growth season (Hollinger, Changnon, 1994). In the paper the starting point is the assumption that there is the correlation between wheat and corn yield and precipitation quantity and maximal and minimal monthly temperature in vegetation period. We selected the crops whose, ,production represents significant segment of agriculture overall development and basis for the cattle breeding and processing industry, which is ultimately the precondition for agro-industrial expansion in Serbia (Stevanović, et al, 2012)."

The examination of correlation between average yield $(\mathrm{y})$ and monthly precipitation quantity and temperature (minimal and maximal) $(\mathrm{x})$ is done according to the following Spearman's formula:

$$
r_{s}=1-6 \sum_{i=1}^{n} \frac{d_{i}^{2}}{n\left(n^{2}-1\right)}
$$

Where: $d i=r(x i)-r(y i), \quad i=1,2,3 \ldots \ldots . N$

Value di represents the subtraction of range value of two variables that are in question, and $\mathrm{N}$ is the number of different series $(\mathrm{N}=21)$.

There are several different factors including anthropogenic and natural factors that influence food production. Future changes would condition complex interactions between weather elements that would be connected to the crop production system. Changes in atmospheric temperature and precipitation could significantly impact crop yield. Crop resistance to climate variations such as temperature and precipitation is the most important (Ndawayo, et.al, 2017).

The achieved correlation coefficient for region Gruža as the result of interdependence between precipitation per month and achieved yield of wheat (Table 2) shows significant connection for weather stations of Kragujevac and Rudnik. Correlation coefficient is negative ( $r s=-0,445 *$ Kragujevac-December; $r s=-0,483 *$ RudnikApril). Negative correlation coefficient means that two variables are connected in a way that if one variable is rising, another one is falling. In this case, that indicates that increase in precipitation causes decrease of wheat yield. Correlation strength is moderate. Correlation level in weather stations of Kragujevac $(0,043)$ and Rudnik $(0,027)$ is statistically significant because it is lower than 0,05 . ,Weather condition during the wheat vegetation have great impact on yield. Lack of precipitation, bad precipitation timing, high average temperatures, as well as temperature fluctuations during vegetation have the negative effect. Adaptation to new conditions and choice of breed which are more tolerant to droughts, with shorter vegetation period, and which go through development stages more quickly, represent a defense mechanism from unfavorable climate change (Stojiljković, et al, 2014)."

Unlike wheat whose vegetation period lasts from October to July, vegetation period of corn is much shorter (April-October) (Marković, Jovanović, 2011). Correlation 
coefficient is the most important in July and August (Table 3). According to data from weather station Kragujevac, the most important correlation coefficient is between precipitation quantity and yield in July and its value is 0,05 . Data from weather stations of Kraljevo and Rudnik show that connection between corn yield and monthly precipitation is the most important in July and August. Correlation coefficient for Kraljevo in July is $r s=0,657$. The correlation is positive and has statistical significance $(0,001)$ on the level 0,01. Correlation coefficient for August is moderate positive ( $\mathrm{rs}=0,507)$ and is statistically significant $(0,019)$ because it is lower than 0,05 . Correlation for Rudnik is highly positive ( $\mathrm{rs}=0,661)$ in July and it has statistical significance $(0,001)$ in relation to significance level 0,01. In August, correlation coefficient is moderate positive $r s=0,472$ and its statistical significance $(0,031)$ is on the level 0,05 .

Usually, it is thought that corn is resistant towards drought and that it consumes water economically. However, since it creates great vegetation, gives high yield, has a long vegetation period, the corn consumes large amounts of water. In lack of water, the corn successfully overcomes drought, but also gives smaller yield, because plants consume different water categories and water types from the soil (Pejić, Bošnjak, et al, 2009).

Table 2.Correlation between monthly precipitation $(\mathrm{mm})$ and wheat yield $(\mathrm{kg} / \mathrm{ha})$ in the region of Gruža for period 1991-2011.

\begin{tabular}{|c|c|c|c|c|c|c|c|c|c|c|c|}
\hline & & \multicolumn{10}{|c|}{ Wheat } \\
\hline & & Oct. & Nov & Dec. & Jan. & Feb. & Mar. & Apr. & May & Jun. & Jul. \\
\hline \multirow{3}{*}{ 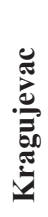 } & Cor. Coef. & ,32 &, 17 &,$- 445^{*}$ & 35 &,- 19 & 02 &,- 30 &, 17 &, 10 &, 17 \\
\hline & $\begin{array}{l}\text { Sig. } \\
\text { (2-tailed) }\end{array}$ &, 15 & ,45 & ,043 &, 11 & ,40 & ,91 & ,17 & ,444 &, 66 & ,44 \\
\hline & $\mathrm{N}$ & 21 & 21 & 21 & 21 & 21 & 21 & 21 & 21 & 21 & 21 \\
\hline \multicolumn{12}{|c|}{ * Correlation is significant at the 0.05 level (2-tailed). } \\
\hline \multirow{3}{*}{ 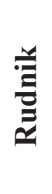 } & Cor. Coef. &, 31 &, 12 &,- 30 & ,39 &,- 28 &,- 14 &,$- 483^{*}$ & ,00 &,- 04 &, 13 \\
\hline & $\begin{array}{l}\text { Sig. } \\
\text { (2-tailed) }\end{array}$ &, 16 & ,60 & ,18 & ,08 & ,20 &, 53 & ,027 & ,98 &, 84 & ,57 \\
\hline & $\mathrm{N}$ & 21 & 21 & 21 & 20 & 21 & 21 & 21 & 21 & 21 & 21 \\
\hline
\end{tabular}

Author processed the data via program SPSS Statistics 25.

Correlation between maximal temperature in weather station Kragujevac and corn yield (Table 4) shows significant relationship in July ( $\mathrm{rs}=-0,538)$ and August $(\mathrm{rs}=-0,496)$. In both months the correlation is moderate negative. This indicates that increase of maximal temperatures leads to decline of the corn yield. Correlation level $(0,012$ and 0,022 ) has a statistical significance and it is lower than 0,05 .

According to the data from weather station Kragujevac, maximal temperature correlation and corn yield in vegetation period has negative direction and in July, high negative 
correlation is expressed $(\mathrm{rs}=-0,646)$ and in August moderate negative correlation ( $\mathrm{rs}=$ $-0,541)$. The correlation is statistically significant because it is smaller (July $=0,002)$ than 0,01 and (August=0,011) 0,05.

Dependent effect analysis of minimal and maximal temperatures during vegetation period on wheat and corn yield is made using Spearman's correlation coefficient for the time period 1991-2011. Correlation analysis showed that dependence of corn is more expressed than dependence of wheat. Regardless of the fact that significant relationship is not expressed, it could be said that small amount of precipitation and high temperatures or ,the drought during the period of seeding and germination, as well as in the phases before wheat maturation, leaves the strongest negative impact on wheat yield (Malešević, et al, 2011)."

Table 3.Correlation between monthly precipitation $(\mathrm{mm})$ and corn yield $(\mathrm{kg} / \mathrm{ha})$ in region of Gruža in the period 1991-2011.

\begin{tabular}{|c|c|c|c|c|c|c|c|c|}
\hline & & \multicolumn{7}{|c|}{ Corn } \\
\hline $\begin{array}{l}\text { Weather } \\
\text { stations }\end{array}$ & & Apr. & May & Jun. & Jul. & Aug. & Sept. & Oct. \\
\hline \multirow{3}{*}{ Kragujevac } & $\begin{array}{l}\text { Correlation } \\
\text { Coefficient }\end{array}$ & ,319 &,- 089 & 077 &, $540^{*}$ & ,392 &,- 155 & , 193 \\
\hline & Sig. (2-tailed) &, 159 & ,700 & ,741 & 012 & ,079 & ,501 & ,402 \\
\hline & $\mathrm{N}$ & 21 & 21 & 21 & 21 & 21 & 21 & 21 \\
\hline & \multicolumn{8}{|c|}{ *Correlation is significant at the 0.05 level (2-tailed). } \\
\hline \multirow{4}{*}{ Kraljevo } & $\begin{array}{l}\text { Correlation } \\
\text { Coefficient }\end{array}$ & ,205 &,- 019 & ,201 &, $657^{* *}$ &, $507^{*}$ &,- 305 & 086 \\
\hline & Sig. (2-tailed) & ,374 & ,935 & ,381 & ,001 & ,019 & ,178 & ,712 \\
\hline & $\mathrm{N}$ & 21 & 21 & 21 & 21 & 21 & 21 & 21 \\
\hline & \multicolumn{8}{|c|}{$\begin{array}{l}* * \text { Correlation is significant at the } 0.01 \text { level (2-tailed). } * \text { Correlation is significant at } \\
\text { the } 0.05 \text { level (2-tailed). }\end{array}$} \\
\hline \multirow{3}{*}{ Rudnik } & $\begin{array}{l}\text { Correlation } \\
\text { Coefficient }\end{array}$ &, 068 &,- 171 & ,155 &, $661^{* *}$ &, $472^{*}$ &,- 179 & ,092 \\
\hline & Sig. (2-tailed) & ,769 & ,459 & ,503 &, 001 & ,031 & ,439 & ,691 \\
\hline & $\mathrm{N}$ & 21 & 21 & 21 & 21 & 21 & 21 & 21 \\
\hline & \multicolumn{8}{|c|}{$\begin{array}{l}* * \text { Correlation is significant at the } 0.01 \text { level (2-tailed). } \\
* \text { Correlation is significant at the } 0.05 \text { level (2-tailed). }\end{array}$} \\
\hline
\end{tabular}

Author processed the data via program SPSS Statistics 25.

Correlation coefficient for weather station Rudnik displays that there is significant relation when it comes to corn, in comparison to wheat. In the corn vegetation period, both minimal and maximal temperatures are significant. Minimal temperature impact is the most prominent in April when correlation coefficient has negative direction and moderate strength $\mathrm{rs}=-0,442$; it is much lower $(0,045)$ than significance level 0,05 but it is statistically significant. It is interesting that, for the same month maximal temperature coefficient has a negative direction and moderate strength $\mathrm{rs}=-0,518$, and also significance level $(0,048)$ is much lower than 0,05 . The correlation in July rs $=$ 
$-0,634$ between minimal temperature and corn yield has negative direction and high correlation. It is statistically significant $(0,015)$ because it is lower than significance level 0,05 .

Correlation between selected climate elements (temperature and precipitation) and corn and wheat yield had statistical significance especially for corn yield. Displayed correlations reflect just those climate impacts which were selected. In the cases when temperature and precipitation with applying Spearman's correlation coefficient did not show statistical significance, such as for example wheat yield, there were important impacts of other factors which were not considered in this research and which could possibly contribute in making trends.

Table 4. The correlation between minimal and maximal temperature $\left({ }^{\circ} \mathrm{C}\right)$ and corn yield (kg/ha) in the region of Gruža for period 1991-2011.

\begin{tabular}{|c|c|c|c|c|c|c|c|c|}
\hline \multicolumn{8}{|c|}{ Corn } & \multirow[b]{2}{*}{ Oct. } \\
\hline $\begin{array}{l}\text { Weather } \\
\text { stations }\end{array}$ & & & Apr. & May & Jun. & Jul. & Aug. & \\
\hline \multirow{3}{*}{ Kragujevac } & \multirow{3}{*}{ 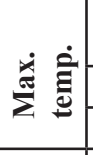 } & Correlation Coefficient &,- 398 &,- 177 &,- 270 &,$- 538^{*}$ &,$- 496^{*}$ & ,015 \\
\hline & & Sig. (2-tailed) &, 074 & ,442 & 237 & ,012 &, 022 & ,949 \\
\hline & & $\mathrm{N}$ & 21 & 21 & 21 & 21 & 21 & 21 \\
\hline & & \multicolumn{6}{|c|}{ *. Correlation is significant at the 0.05 level (2-tailed). } & \\
\hline \multirow{4}{*}{ Kraljevo } & \multirow{4}{*}{ 这 } & Correlation Coefficient &,- 418 &,- 256 &,- 202 &,$- 646^{* *}$ &,$- 541^{*}$ &,- 008 \\
\hline & & \begin{tabular}{|l} 
Sig. (2-tailed) \\
\end{tabular} &, 059 & ,263 & ,379 &, 002 & 011 & ,973 \\
\hline & & $\mathrm{N}$ & 21 & 21 & 21 & 21 & 21 & 21 \\
\hline & & \multicolumn{6}{|c|}{$\begin{array}{l}\text { **. Correlation is significant at the } 0.01 \text { level (2-tailed). } \\
* \text {. Correlation is significant at the } 0.05 \text { level (2-tailed). }\end{array}$} & \\
\hline \multirow{8}{*}{ Rudnik } & \multirow{4}{*}{ 运 官 } & Correlation Coefficient &,$- 518^{*}$ &,- 383 &,- 413 &,$- 634^{*}$ &,- 474 & 223 \\
\hline & & Sig. (2-tailed) & ,048 & ,197 & ,161 &, 015 &, 074 & ,423 \\
\hline & & $\mathrm{N}$ & 15 & 13 & 13 & 14 & 15 & 15 \\
\hline & & \multicolumn{6}{|c|}{ *. Correlation is significant at the 0.05 level (2-tailed). } & \\
\hline & \multirow{4}{*}{ 妾离 } & Correlation Coefficient &,$- 442^{*}$ &,- 183 &,- 208 & 083 &,- 393 &,- 030 \\
\hline & & Sig. (2-tailed) & ,045 & 428 & ,366 & ,721 & ,078 & 897 \\
\hline & & $\mathrm{N}$ & 21 & 21 & 21 & 21 & 21 & 21 \\
\hline & & \multicolumn{6}{|c|}{ *. Correlation is significant at the 0.05 level (2-tailed). } & \\
\hline
\end{tabular}

Author processed the data via program SPSS Statistics 25.

Due to increased expression of correlation coefficient in the area of Gruža between corn yield and climate elements (temperature and precipitation); annual precipitation quantity, and annual minimal and maximal temperatures and corn yield in the time period from 1991 to 2011 are graphically showed, as well as trend line for the corn yield (Figure 1. and Figure 2). 
Figure 1. Annual precipitation quantity $(\mathrm{mm})$ and corn yield in the area of Gruža for the period 1991-2011.

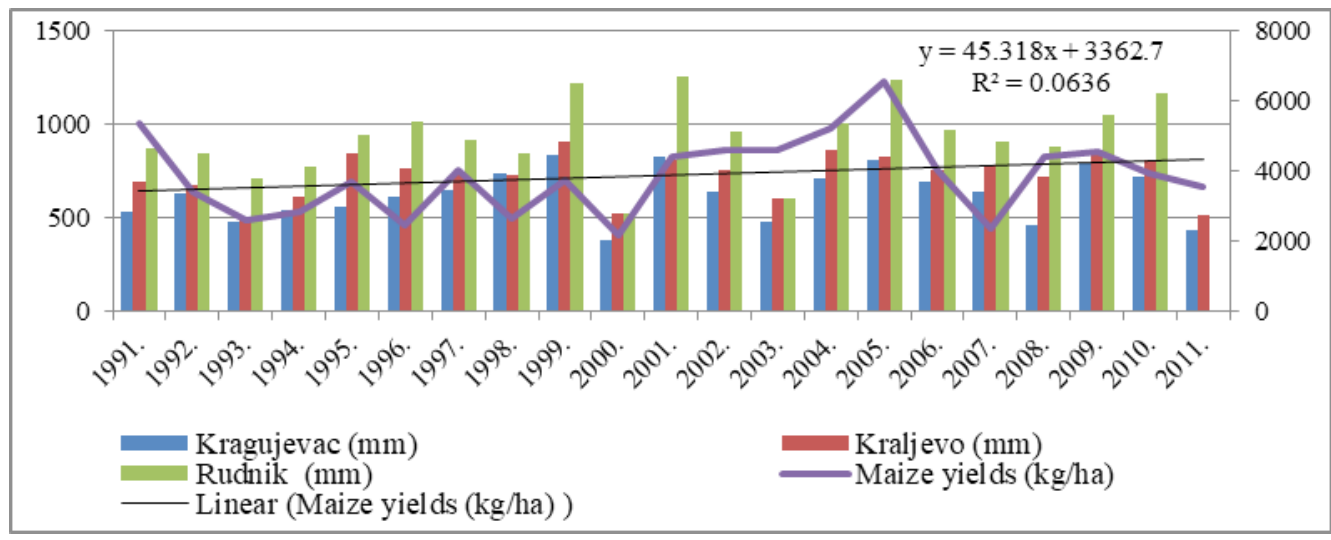

Source: Author processed data from RHMZ and RZS

Agriculture by its nature is highly dependent on the climate change. Different technological solutions are developing and applying with the aim to reduce dependence of agricultural productivity from unpredictable climate conditions. Primarily, this refers to the protective measures against adverse weather conditions (greenhouses, anti-hail rockets, and anti-hail systems), irrigation, and development of breeds and sorts that are resistant to unstable conditions, use of artificial fertilizers and chemical protection agents. Besides all previously written it could be said that agriculture is still very sensitive to unstable climate conditions and thus to long-term climate changes (World Wild Life Fund for Nature, 2012).

Global climate changes and their scenarios accepted by European Commission for Agriculture, suggest that in the area of South and Southeast Europe where our country is located, temperatures would increase, annual precipitation would be reduced, and the hazard from drought and heat waves would be much bigger, which would mean smaller yield of many agricultural crops (European Environment Agency, 2012). „On the territory of Central Serbia, it is expected that, by 2100, winter wheat yield would be smaller for $6 \%$. When it comes to the corn, previous research showed that in the conditions without irrigation, it could be expected reduction of corn yield for $58 \%$ by 2030 , or for $73 \%$ by 2050 . In the case of irrigation, smaller yield reduction could be expected, that is $15 \%$ by 2030 , or $25 \%$ by 2050 . According to estimates, changes in corn yield by 2100 , without irrigation, range from -52 to -22 and for territory between North and West and East and South parts of Serbia (United Nation Development Programme for Development in Serbia, 2015)."

From previously stated, it could be concluded that „climate changes are great reason for concern from the aspect of sustainable development. Finding a solution for adaptation will be very important in the following years, especially when it comes to agriculture. Adaptation measures must strive to reduce the vulnerability of agricultural sector and 
increase sustainability of rural areas, from ecological and economic aspects (European Commission Directorate-General for Agriculture and Rural Development, 2008)." Mitigation and adaptation have the task to reduce the influence of climate changes. The society must adapt to the challenges which arise from climate changes and also it must practice mitigation and adaptation actions. Changes in precipitation quantity and an increasing phenomenon of extreme temperatures, will be one of the most critical factors which determine the overall impact of climate changes to yield of agriculture crops.

Figure 2. Annual (a) maximaland (b) minimal temperatures $\left({ }^{\circ} \mathrm{C}\right)$ in the area of Gruža and corn yield in the time period 1991-2011.

a)

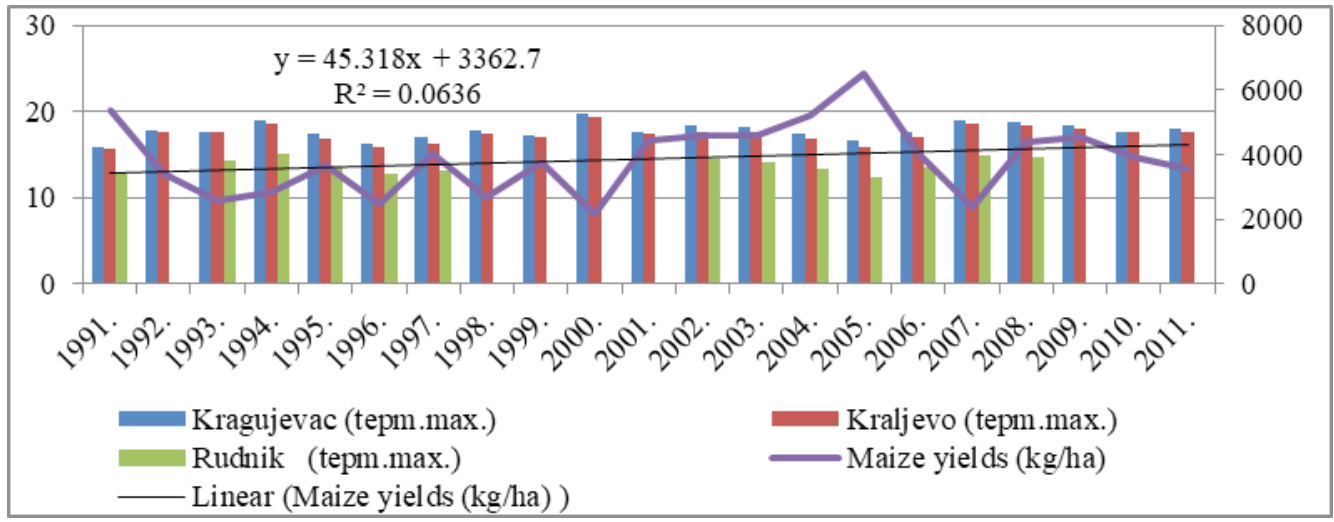

b)

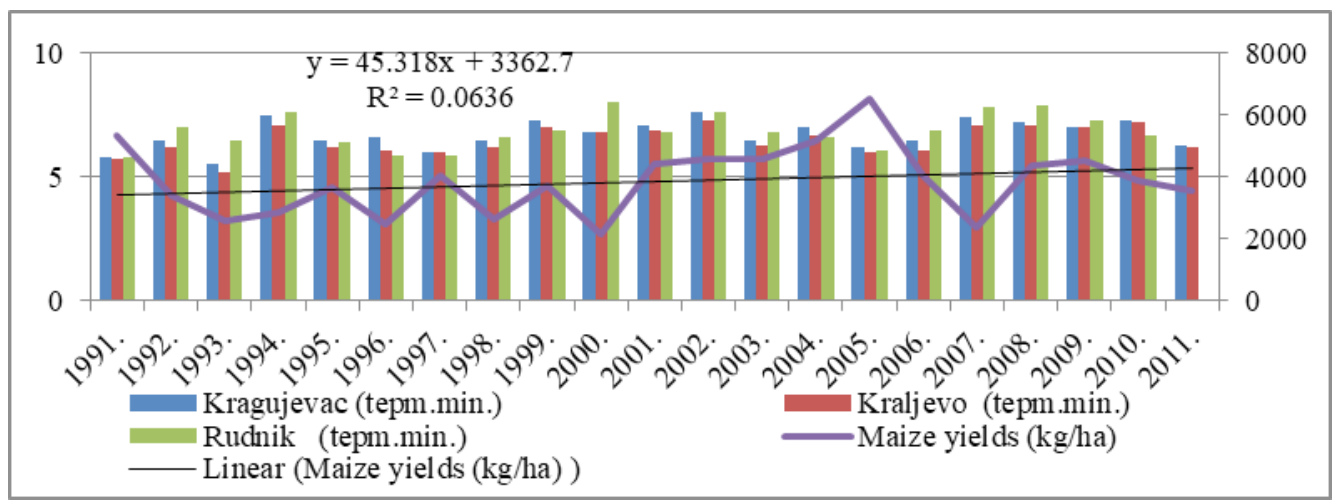

Source: Author processed data from RHMZ and RZS 


\section{Conclusion}

Both current and future climate changes will influence crop yield. This statement has drawn attention of the world, because different aspects of climate variability (temperature, precipitation) impact the crop growth and their productivity results. This study is important because it helps us to understand how climate conditions (temperature and precipitation) and crops (wheat and corn) are related to the time flow, and also it is an insurance for future food production.

As the field of research, it is taken region of Gruža, more precisely county of Knić, which belongs to the group of underdeveloped counties in which citizenship is mostly engaged in agriculture. Climate conditions of the mentioned area are obtained by monitoring condition of climate elements (temperature and precipitation) for the time period 1991-2011 in weather stations of Kragujevac, Kraljevo and Rudnik.

Descriptive statistics has been used in the initial phase of statistical analysis in order to describe the basic features of data. Analysis is made for precipitation and temperature.

The correlation between chosen climate elements and chosen agricultural crops is examined via Spearman's correlation coefficient. When it comes to the climate elements, the starting point is overall monthly precipitation and maximal and minimal monthly temperature for selected weather stations in the precise observation time period, 1991-2011, and yearly wheat and corn yield on the territory of Knić in the same observation time period.

Correlation between precipitation and wheat yield is negative in certain months. This indicates that increased amount of precipitation in months indicated in the table negatively impact wheat yield. At certain stages of growth and development, wheat need for water is different, so the impact to yield would be different.

Correlation coefficient for corn is positive and mostly expressed in summer period. Although, there is a large amount of precipitation then, this indicates that the biggest need of corn for water is in the summer months, or in the vegetation period.

Correlation between maximal temperature (Kragujevac, Kraljevo) and corn yield in summer months (July and August) is negative. Optimal temperature for corn in vegetation period is $24-28^{\circ} \mathrm{C}$. This is due to the extremely high temperatures in that period which could reduce yield and quality. Values of minimal and maximal temperatures in April in weather station Rudnik affect negatively corn yield, as well as the value of maximal temperature in July. Geophysical location of the territory and lower temperatures at higher altitudes unlike for the previous two weather stations have negative influence to the yield of this crop.

Correlation process between maximal temperatures (Kragujevac, Kraljevo, Rudnik) and wheat yield did not show that there were significant correlation when applying Spearman's correlation coefficient. Besides, it could be said that extremely high temperatures in summer period shorten the harvest period and reduce the yield and wheat quality. 
Many researches indicate that negative impact of climate changes to agricultural sector would be especially expressed, because agriculture is directly connected with food production and people's health. It could be concluded that agriculture is dependent on climate change as well as crop yield. However, crop yield is not only influenced by temperature and precipitation. Other natural and anthropogenic factors also have big influence on it.

\section{Conflict of interests}

The authors declare no conflict of interest.

\section{References}

1. Bogdanov, N., \& Babović, M. (2014). Popispoljoprivrede u Republici Srbiji, Radna snaga $i$ aktivnosti poljoprivrednih gazdinstava. Republički zavod za statistiku, Beograd.[Bogdanov, N., \& Babović, M. (2014). Indexing of agriculture in the Republic of Serbia, Labour force and activities of agricultural holdings. The Statistical office of the Republic of Serbia, Belgrade.].

2. European Commission Directorate-General for Agriculture and Rural Development (2008). Climate change:Challenges for agriculture. Brussels, pp. 30 .

3. European Environment Agency (2012). Climate change, impacts and vulnerability in Europe. Copenhagen Denmark, pp. 25.

4. Hollinger, S. E., \&Changnon, S. A. (1994). Response of Corn and Soybean Yields to Precipitation Augmentation and Implications for Weather Modification in Illinois. Southern Illinois University, pp. 4.

5. Jayaraman, T. (2015). The Paris Agreement on Climate Change: Background, Analysis andImplicattions.Review of Agrarian Studies, India,Vol. 5(2), pp. 56.

6. Jovović, A.M., \& Jovičić, B. (2017). Strategija komunikacije za oblast klimatskih promena. Beograd, pp.17.

[Jovović, A.M., \& Jovičić, B. (2017). Communication strategy in the field of climate change. Belgrade, pp.17.].

7. Kelbore, G. Z. (2012). An Analysis of the Impacts of Climate Change on Crop Yields and Yield Variability in Ethiopia. University of Trento, Graduate School of Social Sciences, pp. 2.

8. Malešević, M., Jaćimović, G., \& Jevtić, R. (2011). Iskorišćavanje genetskog potencijalapšeniceuuslovimaabiotičkihstresova.45. Savetovanjeagronoma Srbije, Zlatibor, Zbornik referata, Institut za ratarstvo i povrtarstvo, Novi Sad, pp. 3-14. [Malešević, M., Jaćimović, G., \& Jevtić, R. (2011). The exploitation of genetic potential of wheat under conditions of abiotic stresses. 45 th counseling of Serbian agronomists, Zlatibor, Collections of reports, Institute of Field and Vegetable Crops, Novi Sad, pp.13-14.]. 
9. Marković, T.,\& Jovanović, M. (2011). Uticaj količine padavina na prinos pšenice i kukuruza kao proizvodni bazni rizik. Ratarstvo $i$ povrtarstvo, No. 48 (1), Novi Sad, pp. 210. [Marković, T., \& Jovanović, M. (2011). The effect of precipitation on the yield of wheat and maize as a manufacturing base risk. Crop farming and vegeculture, No. 48 (1), Novi Sad, pp. 210.].

10. Ministarstvo poljoprivrede i zaštite životne sredine. (2015). Zagrevanje useva-kako odgovoriti?Uticaj $i$ promene klime na srpsku poljoprivredu. Program Ujedinjenih nacija za razvoj (UNDP) u Srbiji, Beograd, pp. 8. [The Ministry of Agriculture and Environment Protection.(2015). Heating cropshow to respond? The impact of the climate change on the Serbian agriculture. The United Nations Development Program (UNDP) in Serbia, Belgrade, pp. 8.].

11. Niraj, P. J.,\&Keshav, L. M. (2011). Effect of climate variables on yield of major food-crops in Nepal.School for International Development and Cooperation, Hiroshima University, pp. 1.

12. Ndawayo, B. A.,Nasir, B. S.,\& Alias B. R.(2017). Impact of climate change on maize yield in the maize growing region of Nigeria. International Research Journal of Environmental Sciences, Vol. 6(3), pp. 20.

13. Netherlands Environmental Assessment Agency (2013). EU policy options for climate and energy beyond 2020. The Hague, The Netherlands, pp. 6.

14. Pejić, B., Bošnjak, Đ., \& Mačkić, K. (2009). Response of maize (Zea mays L.) to soil water deficit at specific growth stages. Letopis naučnih radova Poljoprivrednog fakulteta, Vol. 33(1), Novi Sad, pp.156. [Pejić, B., Bošnjak, Đ., \& Mačkić, K. (2009). Response of maize (Zea mays L.) to soil water deficit at specific growth stages. The Yearbook of scientific works of The Faculty of Agriculture, Vol. 33(1), Novi Sad, pp.156.].

15. Republički zavod za statistiku (2013). Popispoljoprivrede 2012. godine. Knjiga 1. [The Statistical office of the Republic of Serbia (2013). Indexing of agriculture in the Republic of Serbia in 2012. Book 1.].

16. Republički zavod za statistiku (2014). Uporedni pregled broja stanovnika 1948, 1953, 1961, 1971, 1981, 1991, 2002. i 2011. godina. Knjiga 20. [Statistical office of the Republic of Serbia (2014). Comparative statistics of the population in the Republic of Serbia in the year 1948, 1953, 1961, 1971, 1981, 1991, 2002 and 2011. Book 20.].

17. Službeni glasnik Republike Srbije br.63/14; Pravilnik za katastarsko klasiranje i bonitiranje zemljišta. Beograd, čl. 43. [The Official Gazette of the Republic of Serbia no 63/14. Bye law of cadastral classification of land. Belgrade, article 43.].

18. Službeni glasnik Republike Srbije br. 62/06, 65/08 - dr. zakon i 41/09. Zakon o poljoprivredi. Beograd, čl. 2. [The Official Gazette of the Republic of Serbia no 62/06, 665/08 - other laws 
41/09. The Agriculture Law. Belgrade, Article no 2.].

19. Službeni glasnik Republike Srbije br.10/13. Zakon o podsticajima u poljoprivredi i ruralnom razvoju. Beograd, čl. 4 . [The Official Gazette of the Republic of Serbia no 10/13. Law on Incentives in Agriculture and Rural Development. Belgrade, Article no 4.].

20. Službeni glasnik Republike Srbije (2015). Zakon o regionalnom razvoju. Beograd, čl.11.

[The Official Gazette of the Republic of Serbia (2015). Law of regional development. Belgrade, Article no 11.].

21. Stevanović, S.,Đorović, M, \&Milanović, M. (2012).The development og the market production of careals in Serbia: Example wheat and corn. Economics of Agriculture, 59(4), pp.618.

22. Stojiljković,J., Biberdžić, M., \& Pešić, B. (2014). Uticaj klimatskih uslova područja na prinos pšenice. XIX savetovanje o biotehnologiji. Zbornik radova, 19(21), Čačak, pp.74.

[Stojiljković, J., Biberdžić, M., \& Pešić, B. (2014). The influence of climatic conditions on the yield of wheat. 19th Conference on biotechnology. Collection of reports, 19 (21), Čačak, pp 74.].

23. Svetski fond zaprirodu (2012). Procena ranjivosti na klimatske promene.

Beograd, pp. 37-38.

[World Wildlife Fund (2012). Assessment of vulnerability to climate changes. Belgrade, pp. 37-38.].

24. The Intergovernmental Panel on Climate Change (2014).Climate Change 2013. The Physical Science Basis, Cambridge University, New York. pp.16.

25. Zar, J.H.(1984). Biostatistical analysis: Englewood Cliffs, N.J., Prentice-Hall, pp.718.

26. http://www.climatechange2013.org/images/report/WG1AR5_ALL_FINAL.pdf (28.8. 2018.)

27. http://www.hidmet.gov.rs/latin/ipcc/index.php(20.6. 2018.)

28. http://www.ipcc.ch/(18.5. 2018.)

29. http://popispoljoprivrede.stat.rs/?cat=1\&lang=lat (20.12.2017.)

30. http://www.stat.gov.rs/ (15.11.2017.)

31. https://mpra.ub.uni-muenchen.de/49466/1/MPRA_paper_49466.pdf (8.5.2018.)

32. http://www.euractiv.rs/odrzivi-razvoj/8826-smanjenje-c02-u-srbiji-napredak-ili-varka. html (14. 2. 2018.)

33. http://www.pbl.nl/sites/default/files/cms/publicaties/PBL_2013-EU-policy-options-forclimate-and-energy-beyond-2020_1082.pdf (19.6.2018.) 